\title{
IN SEARCH OF THE 'FOLK CHARACTER' WE WOULD LIKE TO HEAR \\ THE DICHOTOMY BETWEEN FOLK, THE PROFESSION, AND SCHOLARSHIP
}

\author{
MOJCA KOVAČIČ
}

Public Fund of the Republic of Slovenia for Cultural Activities (JSKD) is the main actor of the current cultural policy in the field of folklore activities in Slovenia. Guidelines of reinterpretation of dance and music traditions are formed by amateurs dealing with folklore, as well as scholars are invited to participate. After the historical review of the cultural policy in Slovenia, the article, based on interviews with performers of musical tradition, reveals the adjustments that musicians are making for the performances organized and supervised by JSKD. It also shows their attitude towards the given guidelines and reveals how much the competitiveness or actual desire for 'authentic' interpretation of folk music heritage influence such adjustments.

Keywords: folk musicians, cultural policy, folk music criteria, researchers.
Javni sklad RS za kulturne dejavnosti (JSKD) je danes glavni akter kulturne politike na področju folklorne dejavnosti $v$ Sloveniji. Smernice za poustvarjanje plesne in glasbene tradicije oblikujejo tako amaterji, ki se ljubiteljsko ukvarjajo sfolklorno dejavnostjo, kot tudi raziskovalci ljudske glasbe in plesa. Članek po uvodnem historičnem pregledu delovanja kulturne politike v Sloveniji, na podlagi intervjujev z ljudskimi godci, odkriva, kako se glasbeniki prilagajajo smernicam, kadar nastopajo na prireditvah, ki jih organizira Javni sklad. Prav tako je predstavljen in interpretiran njihov odnos do danih smernic in vpliv konkurenčnosti oziroma dejanske želje po "verodostojni interpretaciji ljudske glasbene dedišcine na tovrstne spremembe.

Ključne besede: ljudski glasbeniki, kulturna politika, kriteriji ljudske glasbe, raziskovalci

\section{THE IMPACT OF RESEARCHERS: A HISTORICAL VIEW}

In Slovenia there has always been significant relation between folk-music performers and folk-music researchers, and it is hierarchically weighted toward the researchers. One could say that researchers were and still are today the important shapers of cultural policy regarding folk-music culture. The beginning of this synergy can be traced to the time when France Marolt was active as an ethnographer, choir director, composer, and the founder of what is today the Institute of Ethnomusicology. Marolt had a significant impact on shaping the public perception of Slovenian folk music, both through his intervention in dancegroup activities (which were beginning to form into folklore groups during that time) and through his arrangements of folk music. As early as 1935 Marolt held a "Carinthia Day" and the next year a "White Carniola Day" in Ljubljana, two public folk dance festivals. $\mathrm{He}$ continued this work with the Maribor Folklore Festival in 1939. ${ }^{1}$ However, his intentional preservation of folk music and dance tradition also led to forgery of 'original' materials due to the "emphasis on Slovenian authenticity at all costs"(Kumer 1991: 16). At the same

1 The origins of dance folklorism reach all the way back to the second half of the nineteenth century, when organized dance groups performed at various events such as the fortieth and sixtieth anniversaries of Franz Joseph's rule (cf. Kunej 2004: 181). 
time he rejected traditions that he considered 'un-Slovenian' (primarily from the Germanspeaking cultural realm).

After the Second World War one can trace a more systematic approach to cultural policy, which had an indirect impact on folklore activities in Slovenia. From the historical perspective, cultural policy in Slovenia following the Second World War can be divided into four periods according to the establishment or reorganization of the governing bodies involved in shaping amateur cultural activities among Slovenians, which includes folk music and dance:

\begin{tabular}{|c|c|}
\hline $\begin{array}{c}\text { Developmental stages in Slovenian cul- } \\
\text { tural policy (adapted from Čopič 2008) }\end{array}$ & $\begin{array}{l}\text { Organizations in charge of amateur } \\
\text { activity policy }\end{array}$ \\
\hline $\begin{array}{c}\text { Up to 1953: Partially managed cultural } \\
\text { policy when cultural policy was part of } \\
\text { the communist government's propa- } \\
\text { ganda; }\end{array}$ & $\begin{array}{c}\text { - People's Education and Culture Society } \\
(1947-1955) \text { and the Liberty Associa- } \\
\text { tion of Work and Education Societies } \\
(1952-1955) ;\end{array}$ \\
\hline $\begin{array}{l}1953 \text { to 1974: State-managed cultural } \\
\text { policy marked by territorial decentral- } \\
\text { ization (municipalities carry out state- } \\
\text { mandated tasks); }\end{array}$ & $\begin{array}{l}\text { Association of Liberty and Education } \\
\text { Societies (1955-1964) and Slovenian } \\
\text { Association of Cultural and Educa- } \\
\text { tional Organizations (ZKPOS; 1964- } \\
1977) ;\end{array}$ \\
\hline $\begin{array}{l}1974 \text { to 1990: Self-management pe- } \\
\text { riod, during which the management of } \\
\text { cultural policy is transferred to cultural } \\
\text { organizations; }\end{array}$ & $\begin{array}{l}\text { - Slovenian Association of Cultural Or- } \\
\text { ganizations (ZKOS; 1977-1996); }\end{array}$ \\
\hline $\begin{array}{l}1990 \text { to the present: Parliamentary de- } \\
\text { mocracy; that is, the return of cultural } \\
\text { policy to the public authorities and } \\
\text { their cultural administration system. }\end{array}$ & $\begin{array}{l}\text { - Republic of Slovenia Public Fund for } \\
\text { Cultural Activities (1996-pres.) }\end{array}$ \\
\hline
\end{tabular}

The postwar rise in interest in folklore was characterized by a growth in the phenomenon of staged folklore presentations ${ }^{2}$ and "its penetration into cultural policy" (Rihtman-Auguštin 1988: 17). In the first period (up to 1953) interest in folklore still did not show itself because in those times the authorities "repudiate[d] all signs and rituals deriving from former social formations and their agents of power" (Rihtman-Auguštin 1988: 16). It was more noticeable in the second period; that is, the time "when political democratization was accompanied by economic reforms" (Rihtman-Auguštin 1988: 18) and also "the time of tourism development" (Ceribasić 2003: 255). In the realm of amateur and also folklore activities, the

2 Stage presentations of folk music and dance can be understood as a contemporary ritual practice "that fulfills some of the same folk and social needs as those well-rooted, broadly accepted, and professionally approved customs" (Cooley, cited in Ceribašić 2003: 269). 
Slovenian Association of Cultural and Educational Organizations (ZKPOS) was founded at that time. The ZKPOS did not actually have a folklore division, only a professional board whose head was Bruno Ravnikar (appointed in 1967), who was himself involved in folklore as an amateur performer. His varied activities-seminars for leaders of amateur folklore groups, professionally led folklore groups (the Tine Rožanc and Emona groups), publication of a handbook for group leaders called Koreografija ljudskega plesa (Folk Dance Choreography; 1969), and publication of the folklore journal Folklorist (1978-1987)—can be considered an important professional contribution to unifying guidelines for folklore activities. Cultural policy at the time was more active in the area of folk dance, but folk singing and instrumental music followed the same progression a few decades later.

In 1970's the ZKPOS leadership was taken over by Mirko Ramovš, a researcher at the Institut of Ethnomusicology. In the areas of dance and musical folklore, he and his research colleague Zmaga Kumer contributed the most over the next decades to shaping cultural policy guidelines for public presentations of folk music and dance culture. During this period the Yugoslav Folklore Festival in Koper (first held in 1960) flourished under the leadership of Croatian folklore specialist Ivan Ivančan, who stated that "all other similar events in Yugoslavia were based on the model of the Koper festival” (Ivančan 1970: 273). The festival was divided into three parts: in the first 'original' groups performed (according to Ramovš this included groups that presented tradition from their local environment; Ramovš 2011). The second part featured amateur dance groups and the third part professional dance groups (Slovenia did not participate in this third category because it did not have any professional ensembles). In 1970 Slovenian scholars actively participated in preparing the 'Slovenian Day' for the first ('original') part of the festival, for which they specified the guidelines for "making the program of groups characteristically fit the needs of the Koper setting"(Ivančan 1970: 273). This was also the first time vocal groups performed, selected by members of the Institute of Ethnomusicology based on their fieldwork as suitable examples for presenting Slovenian musical tradition at this type of event. At that time also Ramovš took over as head of the folklore committee at the ZKPOS (later ZKOS) and so the annual public stage presentations of folk music and dance in organization of ZKPOS began. ${ }^{3}$ At first these were festivals of folk singers, musicians, and dancers, but later "separate events for singers and musicians and others for folklore groups were established" (Šivic 2007: 27). In 1984 a committee for folklore activities was established at the ZKOS, led by Meta Benčina, who, when planning event guidelines and programming, and preparing educational seminars, always worked closely with scholarly members of the Institute of Ethnomusicology (primarily Zmaga Kumer, Mirko Ramovš, and Julijan Strajnar). During this period the festivals were already well enough known among the public, so the individuals and groups of folk singers and musicians applied to participate, and then professionals selected the performers on the basis of knowing the groups from the field and their suggested repertoires.

3 The first festival was held in Ribnica. 
In the last part of this historical review of the cooperation between the profession and cultural policy, the main impact on cultural policy regarding folklore activities has come from the Republic of Slovenia Public Fund for Cultural Activities (the successor to the ZKOS; hereafter the Public Fund). Because its operation and influence on folk singing has already been discussed in another article (Šivic 2007: 27-41) it will only be briefly touched upon here. The organization is the successor of similar organizations whose work dates back to the eighties of the twentieth century. All the time it cooperate with scholars, who work as the jury or s.c. 'professional consultants' on the folklore festivals and developed criteria that determine the form of 'original'4 Slovenian folk music and dance. Using these criteria, the professional consultants recommend how leaders of folk music groups should best "approximate past musical expression" (Knific s.a.). Institute of Ethnomusicology members are still active as consultants in addition to more prominent amateur participants in folklore activities. Discussions with group leaders are not only advisory but also partially competitive because the advisors then later select the groups that will participate in regional festivals and continue on to the national festival of musicians and singers. The awareness that the musicians and singers at these festivals have various reasons to perform publically and that they come from diverse musical backgrounds (e.g., musicians from folk-pop ensembles, choirs, vocal octets, church singers, choral groups of retirees, musicians from folklore groups, and 'original' singers), and that they are not all 'amateurs' or folk singers and musicians coming from an environment with an continuous musical tradition, led the Public Fund to rename these festivals, which are now literally called Festivals of Singers of Folk Songs and Musicians Playing Folk Tunes.

\section{THE 'PROBLEM’ OF INSTRUMENTAL FOLK MUSIC}

In contrast to dance folklorism, ${ }^{5}$ which is already very well established in terms of stage representations of folk-dance culture, singing groups even today perform in a somewhat more 'original' form, if one takes into account their repertoire and performance practice and the simultaneous inclusion of these groups in the primary context of folk music, ${ }^{6}$ such

4 At the beginning I must point out that certain contested terms such as "folk music," "folklorism," "original music," "tradition," "original context," and "primary context" are considered to be technical terms in this article because problematizing individual terms would interrupt the flow of the article. With the use of terminology as is it is used in the discussed context it is also easier to understand the processes of cultural policy regarding folk music from the inside perspective.

5 In this context, "dance folklorism" means "a change in the social context of dancing (most often as a stage production), as well as changes in the text" (Kunej 2004: 181). This "text" also includes the music.

6 This form of presentation also belongs to the concept of folklorism according to some criteria, by which any faithful performance of the folk is seen as folklorism (Šmidchens 1999: 54). But vice-versa, everything that is understood as folklorism today belongs to folklore (for more on this, see Ceribašić 2003: 264) or is a "part of the folklore process" (Poljak Istenič 2009: 74), and so this division makes no sense. 
as being part of rituals and customs in the local environment. Instrumental musical performance has long been seen as more problematic in terms of performing 'original' music. Since 1950, under the influence of radio, popular music, and the broad popularity of the accordion, instrumental performance has increasingly modeled itself after the example of the ever more popular folk-pop music. The establishment of numerous ensembles and their success in Slovenia and abroad has encouraged partial institutionalization of this type of music-making. Musicians, primarily accordionists, established their own music schools, courses, festivals, and competitions, and folk-pop ensembles increasingly included professionally educated musicians (primarily woodwind and brass players). Folk musicians no longer played the older dance tunes, but instead waltzes and polkas, in wholesale imitation of the Avsenik and Slak ensembles, and later other similar ensembles, both in terms of repertoire selection and performance style. Thus, according to the criteria of "popularity and variation" (Šivic 2008: 15), quite a few folk-pop tunes that have become constituent parts of folk musicians' repertoires have actually been folklorized.

The function of bearers of folk-music tradition has today been taken over by established groups, but their socially accepted folk nature is no longer determined by transfer, variation, or acceptance of musical material among wider community of people, but rather by popularity, visual and acoustic appeal, group structure, and 'folk characterized' repertoire. Information on the growth in releases of recordings of folk instrumental and vocal groups since 1991 also brings this point home. ${ }^{7}$

Groups and individuals that publicly represent themselves as folk musicians often combine vocal and instrumental music ${ }^{8}$ and usually include folk songs and folk-music tunes in their repertoires (in addition to folk-pop and original compositions). They further reinforce their folk image by wearing 'rural' attire (e.g., aprons, hats, etc.). Their instrumentation usually includes diatonic accordion (formally recognized as a folk instrument) and improvised instruments that are associated with the folk and the rural countryside (e.g., washboards, gourds, scythes, etc.).

However, due to the reinterpretation of the folk-pop musical genre-that is, a newly-composed repertoire and/or adopting certain elements of performance practice from folk-pop music - this type of music-making (which by function unavoidably belongs to the phenomenon of folk music-making) is not accepted among scholars as instrumental folk-music.?

7 This information includes only albums that were registered at the Institute of Ethnomusicology; the actual growth in releases is probably even greater.

8 In the past musical tradition, vocal and instrumental music were generally performed separately.

9 Considering that even today we continue to intentionally protect folk music-making from the influence of folk-pop music, it is interesting that in 1980 a seminar for diatonic accordion (organized by the ZKOS) was led by Lojze Slak, one of the two most prominent representatives of folk-pop music in Slovenia. Obviously at that time the need to popularize the diatonic accordion among folklore specialists was the dominant need (cf. Ravnikar 1980: 18), and folk-pop music was not yet seen as a "threat" to folk music-making. 


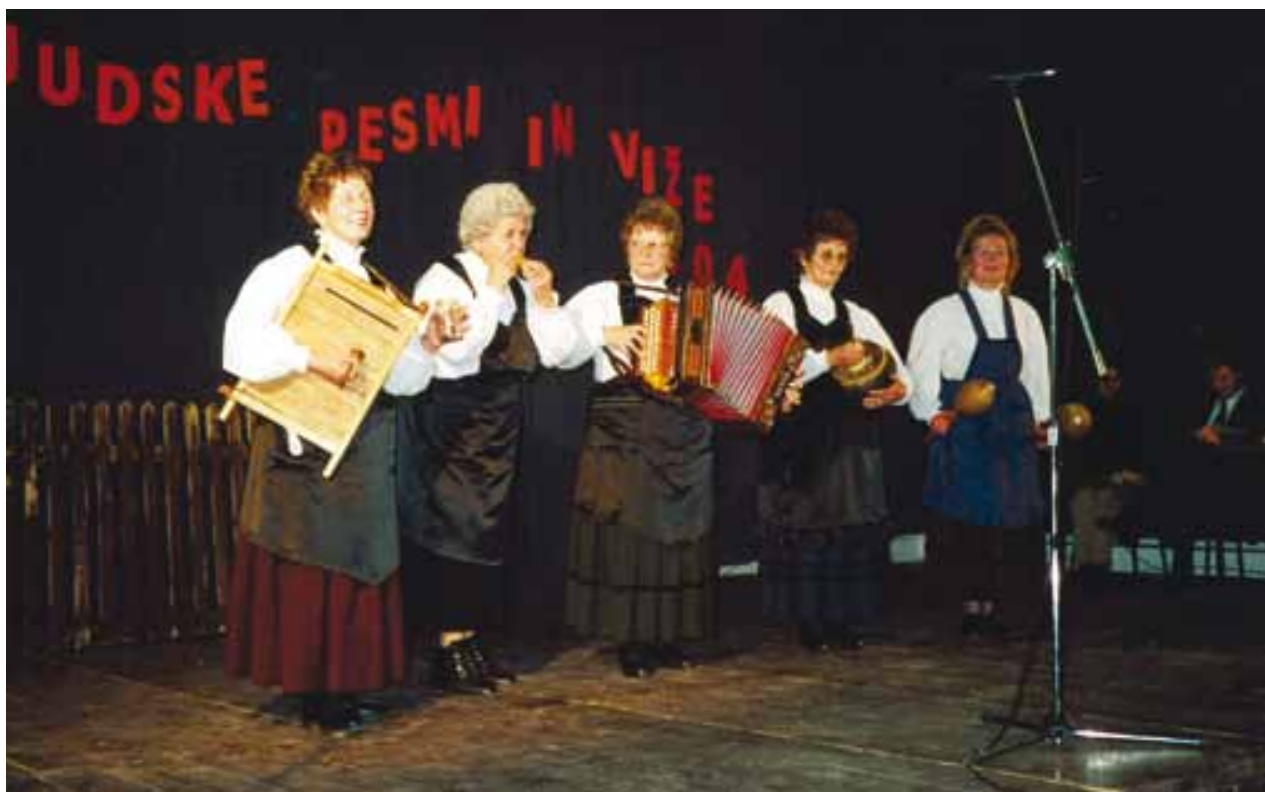

Figure 1: Group of musicians with improvised instruments. (Photo: M. Kovačič)

Thus, there are hardly any instrumentalists at these festivals; the only ensembles that are acceptable are those that come from folklore groups and play folkdance music of the past and musicians that still play some locally colored tunes or marches, waltzes, and polkas that are considered 'old enough'. This leads to inconsistency because the Public Fund's criteria permit "the performance of more recent songs/tunes, if they can be attributed to folk character" (Knific 2009: [2]), in which this 'folk character' is extremely relative and is determined subjectively. As one of the professional consultants to the Public Fund says, "there is no recipe; healthy judgment is ordinarily decisive" (Rauch 2009: 111).

That the scholars are aware of the problem can be seen from the fact that the Public Fund has been holding seminars for several years now, intended for instrumentalists, where they can get to know older techniques and repertoires that are mostly no longer a part of a living traditions. In any case, this type of work leads to the path that folk dance went down (and where the song tradition is also likely headed ${ }^{10}$ ) because it is not to be expected that the repertoire and older ways of playing in 'folk style' will once again spontaneously come to life among the people.

Lately an article appeared in the journal Folklornik (published by the Public Fund) in which the author and professional consultant Vesna Sever discussed her thoughts. She

10 This is already partially true for today's stage presentations by folk singers. Some of them may still use their repertoire in their primary contexts, but there are constantly more singers that perform folk songs exclusively for stage performances. The revitalized form of folk singing (including the repertoire, performance practice, social function, etc.) is increasingly removed from its real life in human society and calendar cycles. 
frequently takes part in the folk music festivals and events organized by individual groups of singers or musicians. At these occasions the groups perform in a manner that generally departs from the Public Fund guidelines and only then is it "a true representation of the status and form of folk music today" (Sever 2011: 19). Although this professional consultant to the Public Fund describes the situation as "wretched" (Sever 2011: 19), awareness is the first step toward objectively understanding this phenomenon. Similarly, based on her study of a vocal-instrumental group, ethnomusicologist Urša Šivic uncovered their dual identity (Šivic 2011: 101-106). That is, the group adapts its use of instruments and performance practices to various situations and therefore performs in line with Public Fund guidelines at the festivals it sponsors, but then performs differently in other contexts.

\section{THE PERFORMER'S PERSPECTIVE, OR THE EMIC PERSPECTIVE}

The articles mentioned above describe the scholarly perspective on the state of folk music today; in the remainder of this article I focus on the performers' perspective on the folklore studies discipline and their relationship to folk music. My examples cite and interpret conversations held with two group leaders, one from an instrumental group and one from a vocal-instrumental group. Both groups are members of the Public Fund and take part at festivals. My primary interest was their view of the Public Fund's cultural policy and what they think the actual effects of the Public Fund's guidelines are on the group activities.

\section{GROUP DESCRIPTION}

The head of the Veseli Jožeki (The Jolly Joes) group, which consists of 9 to 20 accordionists, cited his own need for a musical outlet as a reason for founding the group. He had spent many years as a member of choirs and vocal groups. At the same time he mentioned that he wanted to take over the "disorganized" playing of numerous accordion players in the village and create "a single concept with a head and a tail," or that he "wanted to make something more out of this" (Hrga 2011). That this music-making "got a head and a tail" and became "something more" actually means that it became a part of the local cultural association and began giving public performances at various cultural and tourist events with programs prepared in advance, and the group members began meeting for regular weekly rehearsals. This organization also means that the group does not operate within the local rituals and customs but only in the form of public stage performances. The group has also self-published an album on which they perform folk music and their own newlycomposed music.

Similarly, the other musician, who leads the vocal-instrumental group Stari prijatelji s Kicarja (Old Friends from Kicar), also stated that his own need for a musical outlet was the reason he put the group together. He missed music-making after he bid farewell to his many years of participation in a folk-pop band: "if you play for 38 years, it isn't easy to 
just drop it all at once" (Kocmut 2011). This group of folk musicians and singers includes three married couples, among them two sisters, a brother, and two sisters-in-law, so it is a family ensemble. The group's leader plays piano accordion and the other members play improvised instruments, which their leader made or adapted himself. These include a homemade bass, a washboard, a hunting horn with a metal kazoo inserted into it, an oven fork (a metal tool for moving pots inside a wood-burning oven), a rake, a wine thief (an implement for taking wine from the barrel), and a friction drum. The group performs three ways: only vocally, vocally and instrumentally, or only instrumentally. They have issued four self-released albums of their own newly composed music and folk music.

\section{THE PUBLIC FUND CRITERIA AND MUSICIANS}

Both groups are members of the Public Fund and take part in the festivals it holds. However, due to the criteria mentioned above they both depart from the established professional view of folk music and are therefore always criticized for this after their performances by the professional consultants at these festivals. With regard to the Public Fund criteria, the group Veseli Jožeki is reproached for having many accordions play together because this practice was not known in the past musical tradition. Because most accordionists (primarily young ones) come from the folk-pop musical environment, their music, their style of playing, and the way they bring together playing and singing is reminiscent of folk-pop performance, despite the fact that they (also) perform repertoire that fits the Public Fund criteria. The group's leader also takes part in professional seminars and discussions with Public Fund professional consultants, but he does not adapt to their criteria. In order for this to happen he would have to add new members that play other instruments (primarily woodwinds and brass) and exclude current members (accordionists) from the group. He does not concern himself with the professional comments from the Public Fund consultants and thinks that "they don't need that" (Hrga 2011). He views the professionals' work as limited because they supposedly "would all like to have a button box, one old bass, and a clarinet, but they don't want anything else" (Hrga 2011). His group will still be taking part in the festivals, even though he considers them pointless, and also because they are poorly attended. He claims that the performers already all know each other, and that the rest of the people are not interested in such events anymore: "It bothers me that we ourselves are our only reason to be there. We've already been meeting at these festivals for thirty years. People don't want to come see us anymore" (Hrga 2011). As an example of a successful public event he cites his own event, which he holds every year on St. Joseph's Day (19 March) and is attended by at least 500 people. The 'recipe' for this event's success is its rich program and ongoing selection of new groups. It is interesting that at the beginning he himself also set out some criteria that were in accord with those of the Public Fund: that the older, folk repertoire should be played, and that performers should not be dressed uniformly. ${ }^{11}$ Today in his

11 The Public Fund rejects groups that are dressed uniformly, especially when their clothes are only partial reconstructions of 'old-style' clothing. 
selection of repertoire he allows other genres, and so the event is mixed largely with the folk-pop repertoire, and one can also see performers dressed uniformly (including the Veseli Jožeki group itself). Items of clothing such as hats and aprons are a means of awakening nostalgia for the past and are today a component part of the performers' identification with the Slovenian folk music.

In addition to accordion, the group Stari prijatelji s Kicarja also uses improvised instruments, which is a new development in stage presentations of folk music. They are mostly used as rhythmic accompaniment (except for instruments such as the comb and the kazoo) and are tools in their basic form (e.g., for drawing off wine, mowing hay, doing laundry, etc.). The Public Fund rejects these kinds of instruments because they were supposedly only included in folk music tradition in cases when there were no 'proper' musicians available or when they were celebrating the evening before someone's name day or a newlywed couple after their wedding night. At those times they would make noise with various objects and tools, an activity referred to in Slovenian as 'cat music'12. Just like rural clothing, these instruments are used to create the illusion of authenticity and contribute to the musicians' identification with the folk, the past, the old ways, and so on. This kind of music-making may be understood as part of an invented tradition because its visual and acoustic form gives it legitimacy in the context of preserving ethnic heritage.

The Stari prijatelji s Kicarja group has performed at some festivals as a vocalinstrumental group, although later the professional consultants advised them to drop the instrumental part at Public Fund events and so today it only performs as a group of folk singers. This apparent submission to the Public Fund's criteria has not really changed the leader's opinions, however; he does not agree with the Public Fund's criteria but merely follows them in order to be able to participate in the events and potentially make it to the regional level: "I'm alive, I have my own goals. I don't want to follow those rules any more, those strict ones, except when we go to their festivals. There we sing well, one hundred percent perfectly" (Kocmut 2011). The Stari prijatelji s Kicarja generally perform onstage as part of various cultural and tourist events, where they adapt to the aesthetic criteria of their broader audience:

But I have to say that I don't want to follow those strict rules about this folk stuff any longer. We have lots of songs where we stick to the rules, but we also have other songs because if you want to have a full hall and if you want to get somewhere, you also have to have some of that stuff... these are things that people like ... if you just play in order to be seen onstage that doesn't mean anything. Those are the rules I follow. (Kocmut 2011)

12 Today such instruments are a component part of many folk music groups, usually played by women. Their rapid spread among groups can be ascribed to their simplicity of use because this kind of instrumental playing does not require a lot of musical skill. Groups that play this way also impress their audiences, either with their appearance or with their pronounced rhythmic playing, which encourages a cheerful atmosphere. 
Their group leader also holds an annual event called Kicar poje in igra (Kicar Sings and Plays), which he presents as a festival of folk musicians and singers. Compared to other similar events in the vicinity this event is very successful; each year around 300 people attend. Just like the Veseli Jožeki leader, he also believes that the Public Fund events are poorly attended and that some groups even shun them: "People—some of them don't even want to go to those events because they say it's pointless: you can't play this way, you can't sing that way..." (Kocmut 2011).

The concept of original Slovenian folk music is based on field recordings from the second half of the twentieth century. For most performers this is not an imaginary time that we can only read about in books and scholarly articles, but rather a real time that they lived through. Thus their experiences are also legitimate for determining the appearance of the tradition being reenacted onstage. It is precisely here that complications arise because often these two images do not match. One such example is the fact that professional consultants at festivals promote the separations of vocal performance of songs and instrumental music performances, whereas the leader of Stari prijatelji iz Kicar takes into account the tradition of his own environment, where he believes vocal-instrumental music has always been present:

They [the Public Fund] don't want the accordion to be there ... they say instruments [ought to be] 150 years old. How should I know what those musicians had or what, how should I know. But wait, the accordion is the Slovenian national instrument ... I know, once upon a time we were doing something, and people did sing, God forbid ... but when the accordion came, then the real fun began. And everyone sang, even those who maybe didn't know how to sing. They listened to the melody and then just caught on to it. (Kocmut 2011).

Likewise, he believes that improvised instruments were used because he remembers it himself: "When they were husking corn, I took my accordion, everyone brought something, they quickly grabbed it and picked up the beat" (Kocmut 2011).

Doubt arises at the question of how the profession should promote its viewpoint when it is actually the performers that are legitimate creators of the form of their own musical tradition. And what about when their viewpoints are different?

The Public Fund, they stick to the rules as though their lives depend on it ... They feel differently about that. Now they follow some old tradition, which they got from I don't know where, I don't know how it came to that. The bottom line is they see it differently from those of us who actually experienced it fifty years ago. (Kocmut 2011)

The other contradiction lies in the fact that the profession is basing its opinion regarding the incompatibility of singing and instrumental performance on the general impression gained from numerous field recordings, but at the same time the professional consultants' instructions mention encouraging the preservation of "special features that are known only 
in individual areas, including special features that arose within individual groups" (Knific 2009: [3]). Which special features are acceptable, then?

Contradictions could also be found in the interpretation of the Public Fund guidelines, but it is enough to conclude that the main problem with the guidelines is their focus on musical products (e.g., songs, tunes, clothes, and dances), whereby they forget about other equally valuable elements such as transfers, uses, contexts, and the social environment (Ceribašić 2003: 259). ${ }^{13}$ These are important shapers of folk features, but they are the most difficult or even impossible to recreate.

\section{CONCLUSION OR SOLVING PERSONAL DILEMMAS}

Doubts about the legitimacy of the profession's interference in folk music discussed here exist on both sides. Thus a dual identity arises among performers and researchers that are included in cultural policy processes. I myself had considerable difficulty coming to terms with my relation to the Public Fund and its guidelines. From the professional point of view I support and understand the Public Fund's work, but it is also necessary to understand that this type of presentation does not preserve the original Slovenian folk music tradition, but only one of the forms of its contemporary life, which most often wants to conjure up "a momentary feeling of the past" (Rauch 2008: 53). This involves revitalizing old folk tradition, which is certainly not 'original', 'right', or 'authentic', but merely past (and in some cases also present), and at the same time this is only one possible interpretation of the past. The Public Fund's task is to professionally support one of the older forms of life of folk music and its revitalization, and to educate both musicians and the general public in connection with this. Thus it is understandable that it must "set out some criteria that legitimize the existence of activities" (Rauch 2009: 111). But because folklore phenomena as aesthetic phenomena necessarily also include "the folk aesthetic and aesthetic ideals of individual bearers of folk heritage" (Pisk 2008: 105), we must not judge or even negate the existence of folk music alive today. Thus it is self-evident that the Public Fund criteria will also have to be continuously adapted to the real situation, and above all that researchers must have an objective view of the musical situation. It is precisely instrumental music that has already indicated for several decades that, if we preserve old concepts, we will gradually dedicate ourselves only to revitalizing music-making by folklore instrumental groups. It is necessary to observe contemporary phenomena with the same distance we have today with regard to musical phenomena of fifty years ago. I would like to conclude with the

13 Musical products can most easily be preserved in 'original' form, while musical processes, such as the manner of performance changes alongside musical abilities, knowledge, and performers' interaction with other musical environments. Musical transfer is increasingly often written, learning is becoming systematized, the repertoire is becoming canonized, and in line with the changing context the function is becoming merely performative. 
thoughts of ethnomusicologist Jerko Bezič, who already understood the essence of elements of tradition back in the 1970s: "it is not enough that the musician simply be aware of the great value of tradition; it is also necessary for a particular traditional phenomenon to be a life necessity to that musician: this way it will definitely be maintained and preserved" (Bezić 1973, cited in Ceribašić 2003: 270).

\section{REFERENCES:}

Ceribašić, Naila

2003 Hrvatsko, seljačko, starinsko i domaće: povijest i etnografija javne prakse narodne glazbe u Hrvatskoj. Zagreb: Institut za etnologiju i folkloristiku.

Čopič, Vesna

2008 Slovenia. Historical perspective: cultural policies and instruments (HYPERLINK »http://www. culturalpolicies.net/web/slovenia.php?aid=1 « http://www.culturalpolicies.net/web/slovenia. php?aid=1).

Hrga, Jože

2011 The conversation recording. Accessible at Institute of Ethnomusicology archive: Šikole, 5. 10. 2011, Štaj.

Ivančan, Ivan

1970 Deset godina festivala jugoslovenskog foklora u Kopru. In: Narodna umjetnost: hrvatski časopis za etnologiju i folkloristiku 7(1): 272-273.

Knific, Bojan

[s.a.] Folklorna dejavnost. Področja delovanja (http://www.jskd.si/folklorna-dejavnost/kdo_smo_folklora.htm; http://www.jskd.si/folklorna-dejavnost/kdo_smo_folklora.htm).

2009 Poudarki pri vrednotenju programov. In: Posvet sstrokovnimi spremljevalci srečanjpevcev in godcev. [manuscript]. Ljubljana.

2011 Electronic correspondence, 28. 10.2011.

Kocmut, Janko

2011 The conversation recording. Accessible at Institute of Ethnomusicology archive: Kicar, 5. 10. 2011, Štaj.

Kumer, Zmaga

1991 France Marolt (1891-1951). Traditiones 20: 9-27.

Kunej, Rebeka

2004 Nekateripojavi plesnega folklorizma v Beli krajini do 2. svetovne vojne. Traditiones 33(2): 181-192.

Pisk, Marjeta

2008 Raziskave ljudske pesmi med tekstom in kontekstom. Traditiones 37(1): 99-111.

Poljak Istenič, Saša

2009 Šege in navade kot folklorizem. Traditiones 37(2): 61-110.

Ramovš, Mirko

2011 The conversation recording. Accessible at Institute of Ethnomusicology archive: Ljubljana, 28. 9. 2011., Gor.

Rauch, Tomaž

2008 O priredbah za godčevske zasedbe v folklornih skupinah. In: Folklornik 4: 51-53.

2009 Pogovor s strokovnimi spremljevalci. In: Folklornik 5: 99-114. 
Ravnikar, Bruno

1969 Koreografija ljudskega plesa. Ljubljana: Republiški svet zveze kulturno prosvetnih organizacij Slovenije, Odbor za folkloro.

1980 Folklorist 3/2. Ljubljana: Zveza kulturnih organizacij Slovenije.

Rihtman-Auguštin, Dunja

1988 Folklore. Models and Symbols. In: Rihtman-Auguštin, Dunja in Zorica Rajković (ed.), Contributions to the Study of Contemporary Folklore in Croatia. Zagreb: Zavod za istraživanje folklora (Special Issue; 9), 9-22.

Sever, Vesna.

2011 "Martin skrij harmoniko, Severjeva je tu”. In: Folklornik 7: 8-11:

Šivic, Urša

2007 Vpliv institucionalnih meril na spreminjanje ljudskega petja. Traditiones 36(2):27-41.

2008 Pojezerubliz Triglava:Ponarodevanje umetnih pesmi iz drugepolovice 19. stoletja. Ljubljana: Založba ZRC.

2011 The double identity of traditional musicians : the case of Slovenian vocal-instrumental group from Loka-Rošnja. In: DUNIN, Elsie Ivancich (ed.), ÖCAL, Mehmet (ed.). Proceedings of the second symposium held in İzmir, Turkey, 7-11 April 2010: study group on music and dance in Southeastern Europe. İzmir: International council for traditional music: Ege Univesity State Turkish Music Conservatory, 2011, str. 101-106.

Šmidchens, Guntis

1999 Folklorism Revisited. Journal of Folklore Research 36 (1): 51-70.

\section{ISKANJE LJUDSKOSTI, KI BI SI JO ŽELELI SLIŠATI, ALI RAZPETOST MED LJUDSKIM , STROKO IN ZNANOSTJO}

Dejavnost kulturne politike na področju ljudske glasbe in plesa se je v Sloveniji pričela v šestdesetih letih 20. stoletja, njeni akterji pa so poleg stroke in ljubiteljev vseskozi tudi raziskovalci glasbene in plesne dedišcine. Spodbujanje odrske reprezentacije ljudske glasbe in plesa je vključevalo tudi njeno usmerjanje v, pravilno'poustvarjanje. Ustanova, ki danes vodi, usmerja in podpira ljubiteljsko kulturno dejavnost, je Javni sklad RS za kulturne dejavnosti; delovanje ljudskih pevskih in godčevskih ter folklornih skupin pa ureja njena sekcija za folklorno dejavnost. Ta je v letih svojega delovanja skupaj s selektorji oziroma t.i. strokovnimi spremljevalci odrskih predstavitev ljudske glasbe (srečanj) izoblikovala merila, ki določajo podobo, izvirne' slovenske ljudske glasbe. Na podlagi teh meril strokovni spremljevalci vodjem skupin, ki predstavljajo ljudsko glasbo, svetujejo, kako naj se čim bolj približujejo "preteklim glasbenim izrazom "(Knific). Pri svetovanju sodelujemo tako sodelavci Glasbenonarodopisnega inštituta kot tudi aktivni ljubitelji folklorne dejavnosti, ki so se na tem področju že vidneje uveljavili. Tovrstno svetovanje pa se v zadnjem času predvsem za raziskovalce odstira kot problematično, bodisi z vidika poseganja v dejavnost, ki jo raziskovalec primarno opazuje in raziskuje, bodisi z vidika definiranja meril. ,Pretekli glasbeni izraz'se je izkazal za neoprijemljiv pojem, ki ga je tako časovno in geografsko kot tudi stilno težko definirati (glej tudi Šivic 2007: 27-41).

Največ težav pri prezentaciji ljudske glasbe stroki in raziskovalcem že dalj časa predstavlja godčevstvo, ki je v pričujočem prispevku tudi izpostavljeno. Ljudsko godčevstvo se je tako v repertoarju 
kot v stilu igranja začelo po drugi svetovni vojni močno prepletati z narodnozabavnim žanrom, kar pa je v okviru pojmovanja ljudskega za kulturno politiko nesprejemljivo. Zato se danes na prireditvah, ki jih organizira Javni sklad, z godci in godčevskimi skupinami zelo redko srečamo. Izključevanje ,sodobnega' godčevstva in okvirov kulturne politike (in raziskovalnih okvirov) po eni strani predstavlja protislovje v pojmovanju koncepta ljudskega godca in godčevstva (prim. Kumer 1983: 127-178), po drugi pa vodi do pojava navideznega prilagajanja godcev smernicam kulturne politike. V pričujočem prispevku so na podlagi pogovorov z vodji godčevskih skupin Veseli Jožeki in Stari prijatelji s Kicarja predstavljeni in interpretirani: pogledi godcev na delovanje kulturne politike Javnega sklada; vplivi, ki jih ima Javni sklad na njihovo delovanje; protislovnost nekaterih meril in smernic Javnega sklada. Dvomi o upravičenosti omenjenih posegov stroke v ljudsko glasbeno podobo so na obeh straneh, tako pri izvajalcih kot raziskovalcih, če so neposredno vključeni v procese kulturne politike. Razumevanje, da tovrstna prezentacija ne ohranja ,izvirne', prave' ali, avtentične' slovenske ljudske glasbene tradicije, temveč je le ena izmed oblik sodobnega življenja ljudske glasbe, pa labko te dvome do neke mere pojasni in omili napetosti med izvajalci, stroko in raziskovalci.

Dr. Mojca Kovačič, Institute of Ethnomusicology, ZRC SAZU, Novi trg 2, 1000 Ljubljana, Slovenija, mkovacic@zrc-sazu.si 